\begin{tabular}{|c|c|}
\hline \multirow{3}{*}{ 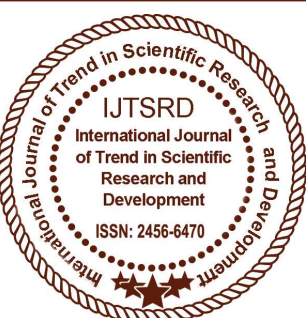 } & $\begin{array}{l}\text { International Journal of Trend in Scientific } \\
\text { Research and Development (IJTSRD) }\end{array}$ \\
\hline & International Open Access Journal \\
\hline & ISSN No: 2456 - 6470 | www.ijtsrd.com | Volume - 2 | Issue - 5 \\
\hline
\end{tabular}

\title{
Effects of Termite Activities on Permeability Characteristics of Lateritic Soils in Ado-Ekiti, South Western, Nigeria
}

\author{
Omoloye E. Abe, Adeyemi E. Adetoro \\ Lecturer, Department of Civil Engineering, \\ Federal Polytechnic, PMB 5351, Ado-Ekiti, Nigeria
}

\begin{abstract}
This research work evaluates the effects of termite activities on permeability characteristics of lateritic soils from two locations in Ado-Ekiti, South Western Nigeria. Six samples were taken from termite mound, that is, two each from top, bottom and where the queen of termite was found. Four other samples were taken from non-reworked surrounding soil. These samples were subjected to permeability tests using grain size distribution and falling head permeameter. The results showed that values of coefficient of permeability obtained using both parameters showed a slight agreement in trend for the two locations. Generally, the values are low but those obtained on soils reworked by termites were observed to be higher than the non-reworked surrounding soils. For instance, the values range from $4.90 \times 10-5 \rightarrow$ to $3.78 \times 10-5$ and $4.60 \times 10-5$ to $4.15 \times 10-5$ for nonreworked soils in locations 1 and 2 respectively, while for termite-reworked soils, slight increases were observed. It ranges from $7.29 \times 10-5$ to $6.10 \times 10-5 \neg \neg$ and $6.95 \times 10-5$ to $4.53 \times 10-5$ for both locations 1 and 2 respectively. It therefore showed that there was a possible alteration of the permeability characteristics of the soil by the activities of the termite.
\end{abstract}

Keywords: $\quad$ Lateritic Soil; $\quad$ Permeability; Permeameter; Reworked; Termite.

\section{INTRODUCTION}

For many soil structures like earth embankments and natural slopes, it is of great importance to study the passage of water through different soil types and soil/rock strata. Also of great importance is the rise of the water in fine-grained soils, especially silts, by capillary action. Beneath the water table, the soil pores are completely filled with water and any

movement of ground water which occurs as a result is assumed to follow Darcy's law [1], which states that the velocity, $\mathrm{V}$ of flow through a column of saturated soil is proportional to the hydraulic gradient (i). To quantitatively determine the rate of flow of water through soil, Darcy defined coefficient of permeability, $\mathrm{k}$ such that $\mathrm{v}=\mathrm{ki}$.

Coefficient of permeability is a function of the shape and size of soil grains, void ratio of the soil, degree of saturation of the soil and the density/viscosity of the liquid. It is to be noted that even in very dense natural soils, the voids between soil particles are connected to the neighbouring voids and it is only this interconnection between voids that makes it possible for water to travel through a soil stratum (Kadyali, 2012). There are various methods of determining the coefficient of permeability of soils and the particular method defined on the type of soil and the field conditions [2]. These methods include:

I. Constant head permeameter for sands and gravels.

II. Falling head permeameter for very fine sands and silts.

For impervious soils such as clays, coefficient of permeability can be determined by an indirect method such as from the results of a consolidation test.

[2] Observed that soil rehabilitation, restoration of vegetative diversity, primary productivity and agricultural potential is stimulated through termite activities. The transport of material to the soil surface by termite loosened the soil, enabling water to infiltrate more rapidly. Termite activity was also found to increase soil porosity or permeability, soil 
saturated hydraulic conductivity, improve soil water status and reduce soil density and soil resistance to come penetration.

Termites are social insects numbering about 3000 known species from which approximately $75 \%$ are classified as soil feeding termites [3]. They are soil animals that are not merely inhabitants, but played a distinctive role in most soil processes. Termites produce large voids that improve soil porosity and walter infiltration [4]. This study was therefore carried out to evaluate the effects of activities of termites on permeability characteristics of some lateritic soils.

\section{Materials and Methods}

The materials used for this research work are samples of termite reworked soils and non-reworked soils from two locations - 1 and 2. From each location, two samples were taken from the upper part of the termite mound (TTRS 1 and 2), another two samples from the queen of termite surrounding (QTRS 1 and 2) and two samples from the bottom of the mound (BTRS 1 and 2). In addition, four different samples were taken from the surrounding soils, four metres away from the fourcardinal points of the mound (NRS 1, 2, 3 and 4). These samples were air dried for several weeks and the coefficients permeability tests were carried out on them in accordance with [6] standards and [5] specifications.

\section{Results and Discussion}

The results of grain size distribution tests on both termite reworked soils and non-reworked surrounding soils are shown in table 1 . The results showed that the soil samples contained a wide range of grain sizes and can therefore be described as being well-graded. It is observed that termite reworked soils have lower amount of fines (making it more stable) than the nonreworked soils.

Table 1: The Results of Grain Size Distribution of the Studied Soils in Percentage

\begin{tabular}{|c|c|c|c|c|c|c|c|c|c|c|c|c|}
\hline & \multicolumn{6}{|c|}{ Surrounding Soil } & \multicolumn{6}{|c|}{ Termite Reworked Soils } \\
\hline Location & Sample & $\begin{array}{c}\% \\
\text { Gravel }\end{array}$ & $\begin{array}{c}\% \\
\text { Sand }\end{array}$ & $\begin{array}{l}\% \\
\text { Silt }\end{array}$ & $\begin{array}{c}\% \\
\text { Clay }\end{array}$ & $\begin{array}{c}\% \\
\text { Fines }\end{array}$ & Sample & $\begin{array}{c}\% \\
\text { Gravel }\end{array}$ & $\begin{array}{c}\% \\
\text { Sand }\end{array}$ & $\begin{array}{l}\% \\
\text { Silt }\end{array}$ & $\begin{array}{c}\% \% \\
\text { Clay }\end{array}$ & $\begin{array}{c}\% \\
\text { Fines }\end{array}$ \\
\hline \multirow[t]{6}{*}{1} & NRS 1 & $1=$ & 24 & 46 & 29 & 175 & TTRS 1 & C 30 & 30 & 31 & 36 & 67 \\
\hline & NRS 2 & 4 & 25 & 25 & 48 & 73 & TTRS 2 & 4 & 29 & 18 & 49 & 67 \\
\hline & NRS 3 & 2 & 45 & 2 & 51 & 53 & QTRS 1 & 8 & 34 & 18 & 40 & 58 \\
\hline & NRS 4 & 3 & 47 & 19 & 31 & 50 & QTRS 2 & 5 & 43 & 15 & 39 & 54 \\
\hline & & & & & & & BTRS 1 & 3 & 56 & 10 & 31 & 41 \\
\hline & & & & & & & BTRS 2 & & 40 & 15 & 38 & 53 \\
\hline \multirow[t]{6}{*}{2} & NRS 1 & 5 & 20 & 14 & 61 & 72 & TTRS 1 & 2 & 62 & 12 & 24 & 36 \\
\hline & NRS 2 & 4 & 23 & 21 & 52 & 73 & TTRS 2 & 12 & 60 & 5 & 23 & 28 \\
\hline & NRS 3 & 2 & 47 & 10 & 41 & 51 & QTRS 1 & 4 & 30 & 18 & 48 & 66 \\
\hline & NRS 4 & 3 & 46 & 5 & 46 & 51 & QTRS 2 & 5 & 58 & 9 & 28 & 37 \\
\hline & & & & & & & BTRS 1 & 3 & 67 & 8 & 22 & 30 \\
\hline & & & & & & & BTRS 2 & 7 & 56 & 8 & 29 & 37 \\
\hline
\end{tabular}

Tables 2 and 3 show the results of permeability and coefficient of uniformity using grain sizes and falling head permeameter respectively for both locations. The permeability values obtained are very low in both cases, though, that of termite reworked soils are higher than the surrounding non-reworked soil. Therefore, the surrounding soils will retain water for fairly long time than the termite-reworked soils. Soils that tend to retain water for a fairly long time are likely to have poor geotechnical properties as highway sub grade materials using falling head permeameter. The values range from $7.10 \times 10^{-5} \mathrm{~mm} / \mathrm{s}^{-}$ to $5.78 \times 10^{-5} \mathrm{~mm} / \mathrm{s}$ and $6.60 \times 10^{-5} \mathrm{~mm} / \mathrm{s}$ to $5.15 \times 10^{-}$ ${ }^{5} \mathrm{~mm} / \mathrm{s}$ for non-reworked soils in locations 1 and 2 respectively while for termite reworked soils, slight increases were observed. It ranges from $5.10 \times 10^{-}$ 
International Journal of Trend in Scientific Research and Development (IJTSRD) ISSN: 2456-6470 ${ }^{5} \mathrm{~mm} / \mathrm{s}$ to $4.29 \times 10^{-5} \mathrm{~mm} / \mathrm{s}$ and $5.36 \times 10^{-5} \mathrm{~mm} / \mathrm{s}$ to both methods show a slight agreement in trend but are $4.36 \times 10^{-5} \mathrm{~mm} / \mathrm{s}$ for both locations 1 and 2 generally low. respectively. Values of permeability obtained from

Table 2: Results of Coefficient of Uniformity, $\mathrm{Cu}$ and Permeability, K, Using Grain Size Distribution

\begin{tabular}{|c|c|c|c|c|c|c|c|}
\hline Location & Samples & $\mathrm{D}_{10}(\mathrm{~mm})$ & $\mathrm{D}_{60}(\mathrm{~mm})$ & $\mathrm{Cu}$ & $\mathrm{D}_{50}(\mathrm{~mm})$ & $\mathrm{D}_{50}^{2}$ & $\mathrm{~K}(\mathrm{~mm} / \mathrm{sec})$ \\
\hline \multirow{10}{*}{1} & NRS 1 & 0.0011 & 0.25 & 227.27 & 0.220 & 0.0484 & $1.728 \times 10^{-6}$ \\
\hline & NRS 2 & 0.0028 & 0.20 & 71.49 & 0.250 & 0.0625 & $2.2 \times 10^{-5}$ \\
\hline & NRS 3 & 0.0024 & 0.32 & 133.33 & 0.080 & 0.0064 & $2.285 \times 10^{-5}$ \\
\hline & NRS 4 & 0.0045 & 0.39 & 86.67 & 0.100 & 0.0100 & $3.57 \times 10^{-5}$ \\
\hline & TTRS 1 & 0.0030 & 0.29 & 96.67 & 0.300 & 0.0900 & $3.213 \times 10^{-4}$ \\
\hline & TTRS 2 & 0.0380 & 0.38 & 10.00 & 0.081 & 0.0066 & $2.342 \times 10^{-5}$ \\
\hline & QTRS 1 & 0.0040 & 0.35 & 87.50 & 0.200 & 0.0400 & $1.428 \times 10^{-4}$ \\
\hline & QTRS 2 & 0.0070 & 0.25 & 35.71 & 0.110 & 0.0121 & $4.3197 \times 10^{-5}$ \\
\hline & BTRS 1 & 0.0032 & 0.36 & 112.50 & 0.310 & 0.0961 & $3.431 \times 10^{-4}$ \\
\hline & BTRS 2 & 0.0021 & 0.40 & 190.48 & 0.190 & 0.0361 & $1.289 \times 10^{-2}$ \\
\hline \multirow{10}{*}{2} & NRS 1 & 0.0023 & 0.20 & 86.96 & 0.019 & 0.0036 & $1.289 \times 10^{-6}$ \\
\hline & NRS 2 & 0.0016 & m $0.240 \mathrm{~m}$ & 150.00 & 0.240 & 0.0576 & $2.056 \times 10^{-4}$ \\
\hline & NRS 3 & 0.0020 & 0.22 & 110.00 & 0.090 & 0.0081 & $2.892 \times \times 10^{-5}$ \\
\hline & NRS 4 & 0.0042 & 0.26 & 61.90 & 0.120 & 0.0144 & $5.141 \times 10^{-5}$ \\
\hline & TTRS 1 & 0.0040 & 0.32 & 80.00 & 0.310 & 0.0961 & $3.431 \times 10^{-4}$ \\
\hline & TTRS 2 & 0.0360 & 0.29 & 8.06 & 0.100 & 0.0100 & $3.57 \times 10^{-5}$ \\
\hline & QTRS 1 & 0.005 & 0.36 & 72.00 & 0.180 & 0.0324 & $1.157 \times 10^{-4}$ \\
\hline & QTRS 2 & 0.005 & 0.25 & 50.00 & 0.160 & 0.0256 & $9.139 \times 10^{-5}$ \\
\hline & BTRS 1 & 0.007 & 0.40 & 57.14 & 0.220 & 0.0484 & $1.728 \times 10^{-4}$ \\
\hline & BTRS 2 & 0.004 & 0.51 & 127.50 & 0.200 & 0.0400 & $1.428 \times 10^{-4}$ \\
\hline
\end{tabular}

Table 3: Results of Permeability Test Using Falling Head Permeameter

\begin{tabular}{|c|c|c|c|c|c|}
\hline \multirow{2}{*}{ Location } & \multirow{2}{*}{ Sample } & \multicolumn{3}{|c|}{ Time Interval } & \multirow{2}{*}{$\mathrm{K} \times 10^{-5}(\mathrm{~mm} / \mathrm{Sec})$} \\
\hline & & $t_{1}$ (sec.) & $t_{2}$ (sec.) & $\left(t_{1}-t_{1}\right)\left(s_{e c}\right)$ & \\
\hline \multirow{10}{*}{1} & NRS 1 & 6.3 & 13.2 & 6.9 & 6.33 \\
\hline & NRS 2 & 5.6 & 11.7 & 6.1 & 7.10 \\
\hline & NRS 3 & 6.5 & 13.8 & 7.3 & 6.78 \\
\hline & NRS 4 & 6.7 & 14.6 & 7.9 & 5.78 \\
\hline & TTRS 1 & 3.8 & 8.0 & 4.2 & 5.12 \\
\hline & TTRS 2 & 4.2 & 8.6 & 4.4 & 4.80 \\
\hline & QTRS 1 & 4.0 & 8.1 & 4.1 & 4.29 \\
\hline & QTRS 2 & 4.5 & 9.0 & 4.5 & 4.64 \\
\hline & BTRS 1 & 3.2 & 8.1 & 4.9 & 5.10 \\
\hline & BTRS 2 & 4.6 & 9.2 & 4.6 & 4.50 \\
\hline
\end{tabular}




\begin{tabular}{|c|c|c|c|c|c|}
\hline \multirow{2}{*}{ Location } & \multirow{2}{*}{ Sample } & \multicolumn{3}{|c|}{ Time Interval } & \multirow{2}{*}{$\mathrm{K} \times 10^{-5}(\mathrm{~mm} / \mathrm{Sec})$} \\
\hline & & $t_{1}(\sec )$. & $t_{2}$ (sec.) & $\left(t_{1}-t_{1}\right)\left(\sec _{0}\right)$ & \\
\hline \multirow{10}{*}{2} & NRS 1 & 5.7 & 12.3 & 6.6 & 5.53 \\
\hline & NRS 2 & 6,4 & 13.2 & 6.8 & 6.40 \\
\hline & NRS 3 & 6.6 & 13.8 & 7.2 & 5.15 \\
\hline & NRS 4 & 5.4 & 11.9 & 6.5 & 6.60 \\
\hline & TTRS 1 & 5.1 & 9.8 & 4.7 & 5.36 \\
\hline & TTRS 2 & 5.8 & 10.9 & 5.1 & 5.06 \\
\hline & QTRS 1 & 4.2 & 8.9 & 4.7 & 4.36 \\
\hline & QTRS 2 & 3.9 & 8.2 & 4.3 & 4.95 \\
\hline & BTRS 1 & 6.0 & 12.6 & 6.6 & 4.53 \\
\hline & BTRS 2 & 5.2 & 11.3 & 6.1 & 4.90 \\
\hline
\end{tabular}

\section{Conclusion}

This analysis of the effects of termite on permeability characteristics of lateritic soils has revealed that coefficient of permeability values obtained by grain size shows a slight agreement in trend with the values obtained using falling lead permeameter. In both locations, these values are generally low but the values obtained on lateritic soils reworked by termites are higher than the non-reworked surrounding soils. This indicates that termite activities have improved the permeability characteristics of the studied soils.

\section{References}

1. Ola, S. A, "Essentials of Geotechnical Engineering," Nigeria, Ibadan, Jericho: University Press Plc, 2013.

2. Terzaghi, K. and Peck R. B., "Soil Mechanics in Engineering Practice," India, New Delhi: Asia Publishing House, 1962.
3. Jones, C. G., Lawton, J. H. and Shachak, M. "Organisms as Ecosystem Engineers," Oikos, vol. 69, pp. 373-386, 1994.

4. Leonard, J. and Rajot, J., "Influence of Termites on Runoff and Infiltration, Quantification and Analysis," Geoderma, vol. 104, pp. 17-40, 2001.

5. American Association of State Highway and Transportation Officials - AASHTO, "Standard Specification for Transportation Materials and Methods of Sampling and Testing (14th Edition)," USA, Washington DC: AASHTO, 1986.

6. British Standard 1377 - BS 1377, "British Standard Methods of Test for Soils for Civil Engineering Purposes," UK, London: British Standards Institution, 1990. 